This article was downloaded by: [de Clercq, Erik]

On: 6 July 2010

Access details: Access Details: [subscription number 923869722]

Publisher Taylor \& Francis

Informa Ltd Registered in England and Wales Registered Number: 1072954 Registered office: Mortimer House, 3741 Mortimer Street, London W1T 3JH, UK

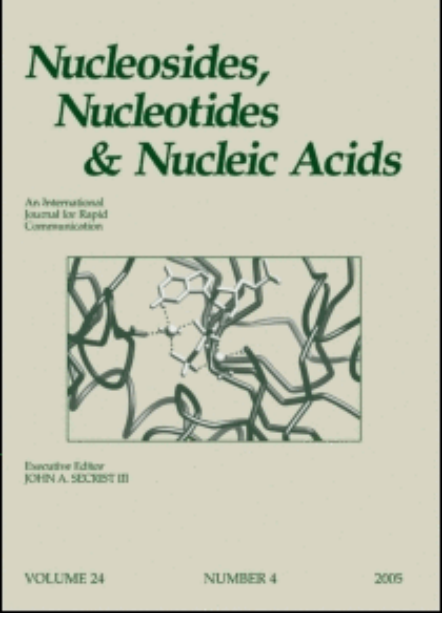

\title{
Nucleosides, Nucleotides and Nucleic Acids
}

Publication details, including instructions for authors and subscription information: http://www.informaworld.com/smpp/title content=t713597286

\section{Synthesis of Novel 6-Azapyrimidine Acyclic Nucleoside Analogues and Antiviral Evaluation}

Malina Jasamai ${ }^{\mathrm{a}}$; Claire Simons ${ }^{\mathrm{b}}$; Jan Balzarini

${ }^{a}$ Faculty of Pharmacy, Universiti Kebangsaan Malaysia, Jalan Raja Muda Abd Aziz, Kuala Lumpur ${ }^{\text {b }}$ Medicinal Chemistry, Welsh School of Pharmacy, Cardiff University, Cardiff, United Kingdom ${ }^{\mathrm{c}}$ Rega Institute for Medical Research, Katholieke Universiteit Leuven, Leuven, Belgium

Online publication date: 28 June 2010

To cite this Article Jasamai, Malina, Simons, Claire and Balzarini, Jan(2010) 'Synthesis of Novel 6-Azapyrimidine Acyclic Nucleoside Analogues and Antiviral Evaluation', Nucleosides, Nucleotides and Nucleic Acids, 29: 7, 535 - 541

To link to this Article: DOI: $10.1080 / 15257771003781634$

URL: http://dx.doi.org/10.1080/15257771003781634

\section{PLEASE SCROLL DOWN FOR ARTICLE}

\footnotetext{
Full terms and conditions of use: http://www.informaworld.com/terms-and-conditions-of-access.pdf

This article may be used for research, teaching and private study purposes. Any substantial or systematic reproduction, re-distribution, re-selling, loan or sub-licensing, systematic supply or distribution in any form to anyone is expressly forbidden.

The publisher does not give any warranty express or implied or make any representation that the contents will be complete or accurate or up to date. The accuracy of any instructions, formulae and drug doses should be independently verified with primary sources. The publisher shall not be liable for any loss, actions, claims, proceedings, demand or costs or damages whatsoever or howsoever caused arising directly or indirectly in connection with or arising out of the use of this material.
} 


\title{
SYNTHESIS OF NOVEL 6-AZAPYRIMIDINE ACYCLIC NUCLEOSIDE ANALOGUES AND ANTIVIRAL EVALUATION
}

\author{
Malina Jasamai, ${ }^{1}$ Claire Simons, ${ }^{2}$ and Jan Balzarini ${ }^{3}$ \\ ${ }^{1}$ Faculty of Pharmacy, Universiti Kebangsaan Malaysia, Jalan Raja Muda Abd Aziz, \\ Kuala Lumpur \\ ${ }^{2}$ Medicinal Chemistry, Welsh School of Pharmacy, Cardiff University, Cardiff, \\ United Kingdom \\ ${ }^{3}$ Rega Institute for Medical Research, Katholieke Universiteit Leuven, Leuven, Belgium
}

\begin{abstract}
- Acyclic nucleosides have been of considerable interest since the approval of aciclovir by the FDA to be used as an antiviral agent in the 1990s. The acyclic moieties and the bases used in the experiment were either available commercially or synthesized using literature methods. Vorbrüggen coupling method was utilized involving reaction of persilylated heterocyclic bases with the appropriate acyclic moiety in the presence of a Lewis acid catalyst. A series of novel 6-azapyrimidine acyclic oxosugar nucleosides was successfully synthesized with a promising yield (more than 50\%). An efficient method of protection and deprotection was also investigated.
\end{abstract}

Keywords Antiviral; 6-azapyrimidine acyclic nucleosides; coupling; deprotection

\section{INTRODUCTION}

Since the approval of aciclovir ${ }^{[1]}$ as an antiviral agent by the U.S. Food and Drug Administration (FDA), there have been numerous publications concerned with the synthesis of acyclic nucleoside analogues with improved biological activity and selectivity compared with aciclovir. Aciclovir is used in the treatment of herpes simplex virus (HSV), varicella zoster virus (VZV), and cytomegalovirus (CMV) infections. ${ }^{[1]}$ Several acyclic nucleoside analogues have been approved for clinical use as antiviral agents; ganciclovir, ${ }^{[2]}$ penciclovir, ${ }^{[3]}$ and valaciclovir. ${ }^{[4]}$

Synthesis of the first 6-azapyrimidine base, 6-azauracil was described by Seibert ${ }^{[5]}$ in 1947. Despite having bacteriostatic ${ }^{[6]}$ and antitumour activities, ${ }^{[7]}$ 6-azauracil was found to be toxic to the central nervous system. ${ }^{[8]}$ Alternatively, 6-azauridine which was synthesized later showed an absence of

Received 29 December 2009; accepted 15 March 2010.

M.J. acknowledges the Malaysian Government for research funding.

Address correspondence to Malina Jasamai, Faculty of Pharmacy, Universiti Kebangsaan Malaysia, Jalan Raja Muda Abd Aziz, 50300, Kuala Lumpur. E-mail: malina@pharmacy.ukm.my 
toxicity $^{[8]}$ and beneficial responses in some hyperplastic diseases. ${ }^{[9]}$ An alkyl substituent ${ }^{[10]}$ at C-5 of nucleoside analogues, propyl group ${ }^{[11]}$ in particular was shown to exhibit significant antiviral activity against HSV.

There are two main methods employed to synthesize the acyclic moiety. Robins et al. ${ }^{[12]}$ reported a synthesis, which involved the preparation of (2acyloxyethoxy) methyl halides as the acyclic moiety. This was achieved by acylation of the cyclic acetal, 1,3-dioxolane ${ }^{[13]}$ by reacting it with either benzoyl chloride or acetyl bromide. ${ }^{[13]}$ Keyser et al. ${ }^{[14]}$ on the other hand, described the preparation of an acyclic moiety which involved the rapid reaction of 1,3dioxolane with trimethylsilyl iodide. The cumbersome method to synthesize the conventional acyclic moiety is no longer required as the compound is commercially available as the protected benzoyloxyethylcloromethylether.

The aim of this study is to synthesize novel acyclic nucleosides using commercially available acyclic moiety, which will be coupled to the 6azapyrimidine bases. The effective method of protection and deprotection will also be examined.

\section{MATERIALS AND METHODS}

\section{Chemistry}

${ }^{1} \mathrm{H}$ and ${ }^{13} \mathrm{C}$ NMR spectra were recorded with a Brucker Avance DPX500 spectrometer operating at 500 and $125 \mathrm{MHz}$, with $\mathrm{Me}_{4} \mathrm{Si}$ as internal standard. Mass spectra were determined by the EPSRC Mass Spectrometry Centre (Swansea, UK). Medac Ltd (Surrey, UK) performed the microanalyses. Flash column chromatography was performed with silica gel 60 (230-400 mesh; Merck, UK) and TLC was carried out on precoated silica plates (kiesel gel $\left.60 \mathrm{~F}_{254}, \mathrm{BDH}\right)$. Melting points were determined on an electrothermal instrument and are uncorrected. Compounds were visualized by illumination under ultraviolet (UV) light $(254 \mathrm{~nm})$ or by the use of vanillin stain followed by charring on a hotplate. All solvents were dried prior to use as described by the handbook, Purification of Laboratory Chemicals ${ }^{[15]}$ and stored over $4 \AA$ A molecular sieves, under nitrogen.

\section{Synthesis of Acyclic Nucleosides}

\section{Benzoic acid 1'-(5-ethyl-6-azauracil)methoxy-ethyl ether (4)}

BSA $(3.50 \mathrm{~mL}, 14.07 \mathrm{mmol})$ was added to a suspension of 5-ethyl-6azauracil (1) (1 g, $7.03 \mathrm{mmol})$ in dry acetonitrile $(20 \mathrm{~mL})$ and the reaction mixture was stirred at room temperature under nitrogen for 30 minutes. A solution of benzoyloxyethylchloromethylether $(3)(1.40 \mathrm{~mL}, 8.08 \mathrm{mmol})$ in dry acetonitrile $(20 \mathrm{~mL})$ was then added. The reaction mixture was cooled in an ice bath before TMSOTf $(2.40 \mathrm{~mL}, 13.36 \mathrm{mmol})$ was added dropwise. The reaction mixture was stirred at room temperature under nitrogen for 3 
hours, diluted with chloroform $(150 \mathrm{~mL})$ and washed with saturated aqueous sodium bicarbonate $(2 \times 100 \mathrm{~mL})$. The organic layer was dried $\left(\mathrm{MgSO}_{4}\right)$ and concentrated in vacuo to give yellowish syrup. Purification by column chromatography (ethyl acetate-petroleum ether 1:1 v/v) yielded compound 4 as a thick white syrup, which gave a white solid on standing (1.25 g, 56\%). $\mathrm{R}_{\mathrm{F}} 0.62$ (ethyl acetate-petroleum ether 1:2 v/v); m.p.: 80-84 ${ }^{\circ} \mathrm{C} ;{ }^{1} \mathrm{H} \mathrm{NMR}$ $\left(\mathrm{CDCl}_{3}\right) \delta 10.59$ (bs, 1, NH), 9.57 (m, 2, o-Ph), $7.44(\mathrm{~m}, 1, p-\mathrm{Ph}), 7.33(\mathrm{~m}$, 2, $m-\mathrm{Ph}), 5.32\left(\mathrm{~s}, 2, \mathrm{H}-1^{\prime}\right), 4.41\left(\mathrm{~m}, 2, \mathrm{H}-4^{\prime}\right), 3.96\left(\mathrm{t}, 2, \mathrm{~J}=4.3 \mathrm{~Hz}, \mathrm{H}-3^{\prime}\right)$, $2.50\left(\mathrm{q}, 2, \mathrm{~J}=7.4, \mathrm{CH}_{2}\right), 1.07\left(\mathrm{t}, 3, \mathrm{~J}=7.3, \mathrm{CH}_{3}\right) \cdot{ }^{13} \mathrm{C}$ NMR $\left(\mathrm{CDCl}_{3}\right) \delta$ $166.68(\mathrm{C}=\mathrm{O}, \mathrm{PhCO}), 156.94(\mathrm{C}=\mathrm{O}, \mathrm{C}-2), 149.77$ (C, C-5), $148.47(\mathrm{C}=\mathrm{O}$, C-4), $133.40(\mathrm{CH}, p-\mathrm{Ph}), 130.16$ (C, COCPh), 129.91 (CH, 2 х $o-\mathrm{Ph}), 128.66$ $(\mathrm{CH}, 2 \times m-\mathrm{Ph}), 79.91\left(\mathrm{CH}_{2}, \mathrm{C}-1^{\prime}\right), 68 . \overline{4} 4\left(\mathrm{CH}_{2}, \mathrm{C}-3^{\prime}\right), 64.37\left(\mathrm{CH}_{2}, \mathrm{C}-4^{\prime}\right)$, $22.96\left(\mathrm{CH}_{2}\right), 10.60\left(\mathrm{CH}_{3}\right) ; \mathrm{IR}_{\operatorname{Vmax} / \mathrm{cm}^{-1}}(\mathrm{NaCl}$, film $) 1719.7(\mathrm{C}=\mathrm{O}), 1451.8$ $(\mathrm{C}=\mathrm{C}$ aromatic stretch), 1275.8-1094.1 (C-O) stretch; MS (ES+) m/z: 342.1 $[\mathrm{M}+\mathrm{Na}]^{+}$; Microanalysis calculated for $\mathrm{C}_{15} \mathrm{H}_{17} \mathrm{~N}_{3} \mathrm{O}_{5}$ (319.3164). C, 56.42\%, $\mathrm{H}, 5.37 \%, \mathrm{~N}, 13.16 \%$. Found C, $56.46 \%, \mathrm{H}, 5.46 \%, \mathrm{~N}, 12.89 \%$.

\section{Benzoic acid 1'-(5-propyl-6-azauracil)methoxy-ethyl ether (5)}

BSA (2.20 mL, $8.96 \mathrm{mmol})$ was added to a suspension of 5-propyl-6azauracil (2) $(0.70 \mathrm{~g}, 2.18 \mathrm{mmol})$ in dry acetonitrile $(20 \mathrm{~mL})$ and the reaction mixture was stirred at room temperature under nitrogen for 30 minutes. A solution of benzoyloxyethylchloromethylether $(3)(0.90 \mathrm{~mL}, 5.15 \mathrm{mmol})$ in dry acetonitrile $(20 \mathrm{~mL})$ was then added. The reaction mixture was cooled in an ice bath before TMSOTf $(1.50 \mathrm{~mL}, 8.51 \mathrm{mmol})$ was added dropwise. The reaction mixture was stirred at room temperature under nitrogen for 3 hours, diluted with chloroform $(150 \mathrm{~mL})$ and washed with saturated aqueous sodium bicarbonate $(2 \times 100 \mathrm{~mL})$. The organic layer was dried $\left(\mathrm{MgSO}_{4}\right)$ and concentrated in vacuo to give yellowish syrup. Purification by column chromatography (ethyl acetate-petroleum ether 3:2 v/v) yielded compound 5 as a thick clear syrup, $(0.36 \mathrm{~g}, 49 \%) . \mathrm{R}_{\mathrm{F}} 0.56$ (ethyl acetate-petroleum ether $1: 2 \mathrm{v} / \mathrm{v}) ;{ }^{1} \mathrm{H}$ NMR $\left(\mathrm{CDCl}_{3}\right) \delta 10.23$ (bs, 1, NH), $8.08(\mathrm{~m}, 2, o-\mathrm{Ph})$, $7.59(\mathrm{~m}, 1, p-\mathrm{Ph}), 7.46(\mathrm{~m}, 2, m-\mathrm{Ph}), 5.43$ (s, 2, H-1'), 4.52 (t, 2, J = 4.6 Hz, H-4' $4^{\prime}, 4.05$ (t, 2, J = 5.0 Hz, H-3'), 2.58 (t, 2, J = 7.6 Hz, CH 2 ), 1.66 (q, 2, $\left.\mathrm{J}=7.5 \mathrm{~Hz}, \mathrm{CH}_{2}\right), 0.99\left(\mathrm{t}, 3, \mathrm{~J}=7.3 \mathrm{~Hz}, \mathrm{CH}_{3}\right) \cdot{ }^{13} \mathrm{C} \mathrm{NMR}\left(\mathrm{CDCl}_{3}\right) \delta 166.93$ $(\mathrm{C}=\mathrm{O}, \mathrm{PhCO}), 156.94(\mathrm{C}=\mathrm{O}, \mathrm{C}-2), 149.48$ (C, C-5), 147.87 (C=O, C-4), 133.57 (CH, p-Ph), 130.32 (C, COCPh), $130.10(\mathrm{CH}, 2 \times$ o-Ph), $128.82(\mathrm{CH}$, $2 \times m-\mathrm{Ph}), 80.05\left(\mathrm{CH}_{2}, \mathrm{C}_{-1}{ }^{\prime}\right), 68 . \overline{62}\left(\mathrm{CH}_{2}, \mathrm{C}-3^{\prime}\right), 64.21\left(\mathrm{CH}_{2}, \mathrm{C}-4^{\prime}\right), 31.97$, $\left(\mathrm{CH}_{2}\right), 20.02\left(\mathrm{CH}_{2}\right) 14.11\left(\mathrm{CH}_{3}\right) ; \mathrm{IR}_{\operatorname{Vmax} / \mathrm{cm}^{-1}}(\mathrm{NaCl}$, film $) 1719.9(\mathrm{C}=\mathrm{O})$, 1451.8 ( $\mathrm{C}=\mathrm{C}$ aromatic stretch), 1275.1-1095.6 (C-O stretch); LRMS (ES+)

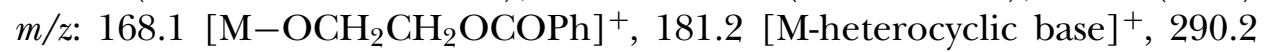

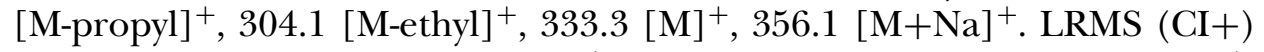
$m / z: 149.0\left[\mathrm{M}-\mathrm{CH}_{2} \mathrm{CH}_{2} \mathrm{OCOPh}\right]^{+}, 167.1\left[\mathrm{M}-\mathrm{CH}_{2} \text { heterocyclic base }\right]^{+}$, $184.1\left[\mathrm{M}-\mathrm{OCH}_{2} \text { heterocyclic base }\right]^{+}, 212.1[\mathrm{M}-\mathrm{OCOPh}]^{+}, 334.2[\mathrm{M}+\mathrm{H}]^{+}$. 
HRMS (ES+) m/z: Calculated mass: $351.1663\left[\mathrm{M}+\mathrm{NH}_{4}\right]^{+}$. Accurate mass: 351.1662

\section{2-(5-Ethyl-6-azauracil)methoxy-ethanol (6)}

Aqueous methylamine $(25 \mathrm{~mL})$ was added to compound 4 (1.09 g, $3.40 \mathrm{mmol}$ ) and the resulting lilac solution was heated on a steam bath for 15 minutes. The lilac colour faded on heating. The crude product was concentrated in vacuo. Purification by column chromatography (methanoldichloromethane 3:97 v/v) yielded white solids. Further purification by recrystallization using ethyl acetate gave compound $\mathbf{6}$ as a white solid (0.61 g, 83\%). R 0.32 (methanol-dichloromethane 1:9 v/v); m.p.: 91-93 ${ }^{\circ} \mathrm{C} ;{ }^{1} \mathrm{H}$ NMR (DMSO-d 6 ) $\delta 12.15$ (bs, 1, NH), 5.17 (s, 2, H-1'), 4.64 (bs, 1, OH), 3.55 $\left(\mathrm{t}, 2, \mathrm{~J}=4.8 \mathrm{~Hz}, \mathrm{H}-4^{\prime}\right), 3.46\left(\mathrm{t}, 2, \mathrm{~J}=4.4 \mathrm{~Hz}, \mathrm{H}-3^{\prime}\right), 2.48(\mathrm{q}, 2, \mathrm{~J}=7.4 \mathrm{~Hz}$, $\left.\mathrm{CH}_{2}\right), 1.08\left(\mathrm{t}, 3, \mathrm{~J}=7.4 \mathrm{~Hz}, \mathrm{CH}_{3}\right) \cdot{ }^{13} \mathrm{C}$ NMR $\left(\mathrm{DMSO}_{6}\right) \delta 157.19(\mathrm{C}=\mathrm{O}$, C-2), 149.31 (C, C-5), 147.21 (C=O, C-4), $79.32\left(\mathrm{CH}_{2}, \mathrm{C}-1^{\prime}\right), 71.39\left(\mathrm{CH}_{2}\right.$, C-3 $\left.{ }^{\prime}\right), 60.43\left(\mathrm{CH}_{2}, \mathrm{C}_{-} 4^{\prime}\right), 22.96\left(\mathrm{CH}_{2}\right), 10.61\left(\mathrm{CH}_{3}\right) ; \mathrm{IR}_{\operatorname{Vmax} / \mathrm{cm}^{-1}}(\mathrm{KBr}, \operatorname{disc})$ 3464.1-3429.3 (O-H stretch), 2984.7-2778.7 (C-H stretch), 1713.8 (C=O), $1444.7\left(\mathrm{C}-\mathrm{O}\right.$ stretch). MS (ES+) $m / z: 238.1[\mathrm{M}+\mathrm{Na}]^{+}$; Microanalysis calculated for $\mathrm{C}_{8} \mathrm{H}_{13} \mathrm{~N}_{3} \mathrm{O}_{4}$ (215.2085). C, 44.65\%, H, 6.09\%, N, 19.52\%. Found C, $44.83 \%, \mathrm{H}, 6.17 \%, \mathrm{~N}, 19.28 \%$.

\section{2-(5-Propyl-6-azauracil)methoxy-ethanol (7)}

Aqueous methylamine $(17 \mathrm{~mL})$ was added to compound $5(0.73 \mathrm{~g}, 2.18$ $\mathrm{mmol}$ ) and the resulting clear solution was heated on a steam bath for 15 minutes. The crude product was concentrated in vacuo. Purification by column chromatography (methanol-dichloromethane 3:97 v/v) yielded white solids. Further purification by recrystallization using ethyl acetate gave compound 7 as a white crystalline solid $(0.42 \mathrm{~g}, 84 \%) . \mathrm{R}_{\mathrm{F}} 0.38$ (methanoldichloromethane 1:9 v/v); m.p.: 90-91 ${ }^{\circ} \mathrm{C}$; ${ }^{1} \mathrm{H}$ NMR $\left(\mathrm{DMSO}_{6}\right) \delta 10.13$ (bs, 1, NH), 5.39, (s, 2, H-1' ), 3.79 (m, 4, H-4' \& H-3'), 2.82 (t, 1, J = 7.5 Hz, $\mathrm{OH}), 2.60\left(\mathrm{t}, 2, \mathrm{~J}=7.5 \mathrm{~Hz}, \mathrm{CH}_{2}\right), 1.68\left(\mathrm{q}, 2, \mathrm{~J}=7.5 \mathrm{~Hz}, \mathrm{CH}_{2}\right), 1.00$ (t, 3, $\left.\mathrm{J}=7.3 \mathrm{~Hz}, \mathrm{CH}_{3}\right) .{ }^{13} \mathrm{C}$ NMR $\left(\mathrm{DMSO}_{6}\right) \delta 156.95(\mathrm{C}=\mathrm{O}, \mathrm{C}-2), 149.68(\mathrm{C}$, C-5), $\left.147.80(\mathrm{C}=\mathrm{O}, \mathrm{C}-4), 80.26\left(\mathrm{CH}_{2}, \mathrm{C}-1^{\prime}\right), 71.74\left(\mathrm{CH}_{2}, \mathrm{C}_{-}\right)^{\prime}\right), 61.99\left(\mathrm{CH}_{2}\right.$, C-4' $\left.{ }^{\prime}\right)$, 32.02, $\left(\mathrm{CH}_{2}\right), 20.08\left(\mathrm{CH}_{2}\right) 14.11\left(\mathrm{CH}_{3}\right) ; \mathrm{IR}_{\operatorname{Vmax} / \mathrm{cm}^{-1}}(\mathrm{KBr}$, disc $) 3433.7$ $(\mathrm{O}-\mathrm{H}), 2966.2-2833.1$ (C-H stretch), $1704.2(\mathrm{C}=\mathrm{O}), 1441.6(\mathrm{C}-\mathrm{O}$ stretch); LRMS (ES+) $m / z: 252.1[\mathrm{M}+\mathrm{Na}]^{+}, 267.9[\mathrm{M}+\mathrm{K}]^{+}$. LRMS (EI+) $m / z: 156.2$

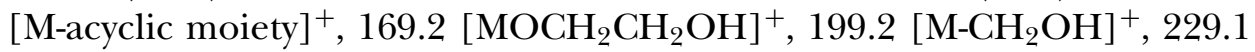

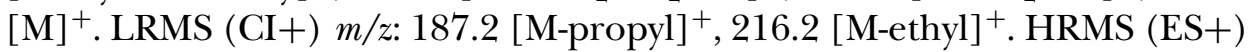
$m / z$ : Calculated mass: 247.1401 $\left[\mathrm{M}+\mathrm{NH}_{4}\right]^{+}$. Accurate mass: 247.1398

\section{Antiviral Assay}

CEM cells in complete medium infected with $100 \mu \mathrm{L}$ of human immunodeficiency virus (HIV) type 1 and 2 were seeded at $4 \times 10^{4}$ cells into 
$0.32 \mathrm{~cm}^{2}$ wells of a 96 -well microplate containing $100 \mu \mathrm{L}$ various concentrations of test compounds $(100 \mu \mathrm{M}, 20 \mu \mathrm{M}, 4 \mu \mathrm{M}$, and $0.8 \mu \mathrm{M})$. Virus stock used in the experiment had a titre of $10^{3.7} \mathrm{CCID}_{50} / \mathrm{mL}$. In the control wells, $200 \mu \mathrm{L}$ of medium containing CEM cells and the virus with no test compound was pipetted. To assess toxicity of the test compound, $100 \mu \mathrm{L}$ of CEM cells alone without the viruses was seeded into the wells containing $100 \mu \mathrm{L}$ of medium and test compound at different concentrations. The microplates were then incubated at $37^{\circ} \mathrm{C}$ for 4 days.

\section{RESULTS AND DISCUSSION}

\section{Chemistry}

The synthesis involved coupling of the heterocyclic 6-azapyrimidine bases (compound 1 and 2) synthesized as reported by Chang ${ }^{[16]}$ with commercially available acyclic moiety (3) using the Vorbrüggen coupling method. ${ }^{[17]}$ Deprotection of the benzoyl protecting group gave the desired acyclic nucleoside analogues (6 and 7) (Scheme 1).

The 6-azapyrimidine bases exist as tautomers, where the lactim form can participate in the coupling reaction, making it necessary to temporarily
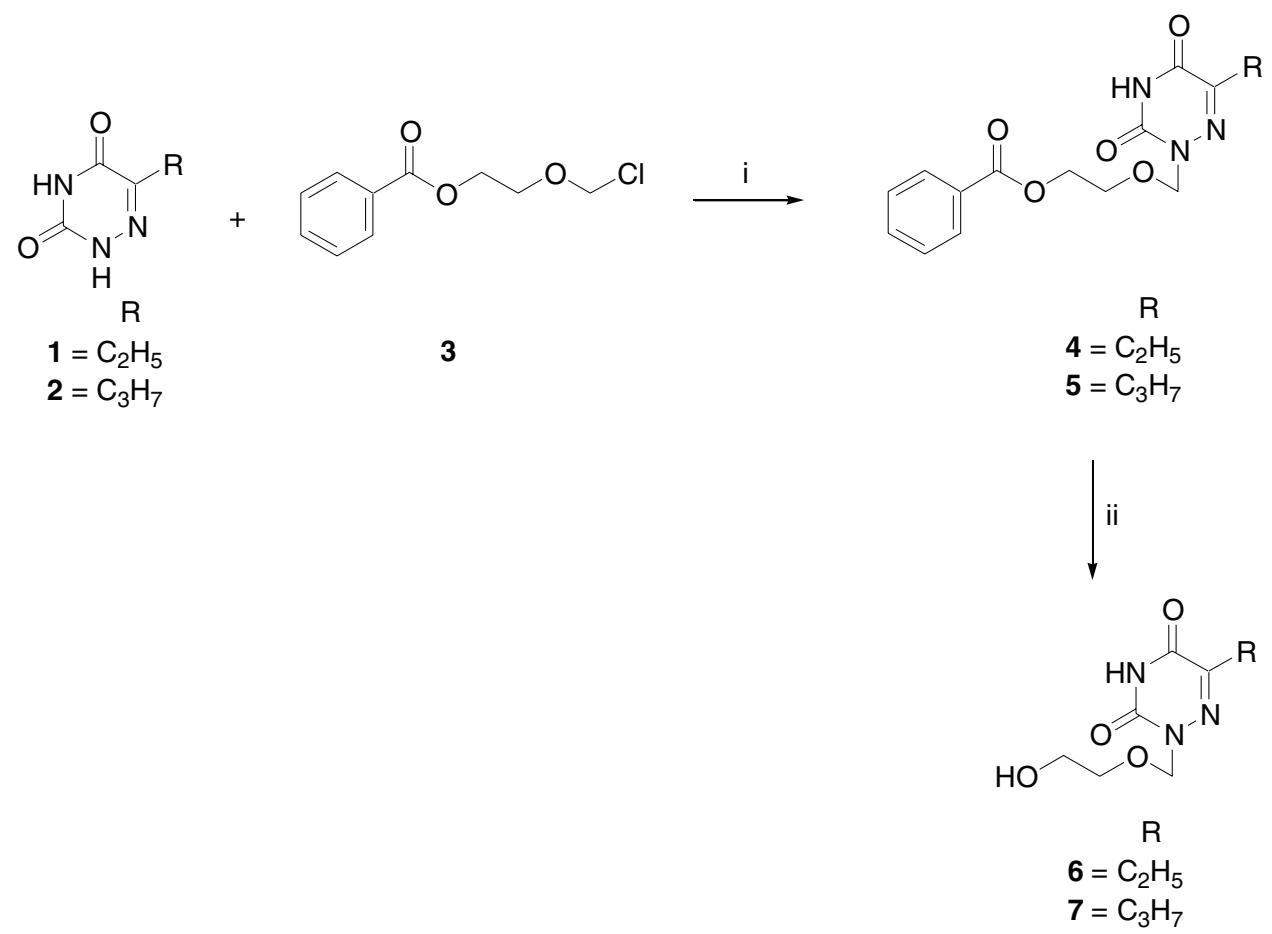

SCHEME 1 Reagents and Conditions: i) dry acetonitrile, BSA, under nitrogen, room temperature, TMSOTf, 3 hours; ii) aq. methylamine, steam bath, 15 minutes. 
protect these groups using bis(trimethylsilyl)acetamide (BSA) as described in the literature. ${ }^{[18]}$ Silylated $\mathbf{1}$ and $\mathbf{2}$ obtained are soluble in acetonitrile yeilding a clear solution on completion of the reaction. The completion of the reaction could not be monitored by thin layer chromatography (TLC) as the $R_{F}$ value of the reactant $(3)$ and the products ( 4 and 5 ) were very close. From preliminary study, the reaction was completed after 3 hours.

The presence of the aromatic group was confirmed by the aromatic signals at 7.33-8.11 ppm in the ${ }^{1} \mathrm{H}$ NMR spectrum and at $128.70-133.60 \mathrm{ppm}$ in the ${ }^{13} \mathrm{C}$ NMR spectrum. Importantly, the occurrence of the H-1 signals at 5.32-5.83 ppm in the ${ }^{1} \mathrm{H}$ NMR spectrum and C-1 signals at 79.91-84.52 ppm in the ${ }^{13} \mathrm{C}$ NMR spectrum indicates that the acyclic moiety had coupled to the respective bases forming the $N$-glycosidic bond. ${ }^{[19]}$

Deprotection of the benzoyl group was achieved by reacting compound 4 and 5 with methylamine on a steam bath for 15 minutes. ${ }^{[20]}$ The reaction was monitored by TLC The impurities, including $N$-methylbenzamide, were removed from the crude product by column chromatography (ethyl acetatepetroleum ether). Pure $\mathbf{6}$ and $\mathbf{7}$ were obtained by recrystallization with ethyl acetate. The disappearance of the benzoyl protecting group in the ${ }^{1} \mathrm{H}$ NMR and ${ }^{13} \mathrm{C}$ NMR spectra confirmed the presence of the desired compounds 6 and 7 .

A series of novel 6-azapyrimidine acyclic nucleosides was successfully synthesized by coupling the commercially available acyclic moiety with the respective 6-azapyrimidine bases using the Vorbrüggen coupling procedure. ${ }^{[17]}$ An effective deprotection of the benzoyl group was achieved by employing method described by Kelly et al. ${ }^{[20]}$

\section{Antiviral Activity}

The acyclic nucleoside analogues synthesized are neither toxic to CEM cells at concentrations up to $100 \mu \mathrm{M}$ nor active against HIV-1 and HIV-2 virus. The acyclic analogues ( 6 and 7 ) obtained have potential to be developed as antiviral drug due to their non-toxic property in vitro. Further studies on the relevant functional groups are needed to improve antiviral activity of the nucleoside analogues synthesized.

\section{REFERENCES}

1. Wagstaff, A.J.; Faulds, D.; Goa, K.L. Aciclovir. A repraisal of its antiviral activity, pharmacokinetic properties and therapeutic efficacy. Drugs. 1994, 47, 153-205.

2. Smith, K.O.; Galloway, K.S.; Kennell, W.L.; Ogilvie, K.K.; Radatus, B.K. A new nucleoside analogue, 9-(1, 3-dihydroxy-2-propomethyl) guanine, highly active in vitro against herpes simplex virus type 1 and 2. Antimicrob. Agents Ch. 1982, 22, 55-61.

3. Boyd, M.R.; Bacon, T.H.; Sutton, D.; Cole, M. Antiherpes activity of 9-(4-hydroxy-3-hydroxymethylbut1-yl)guanine (BRL 39123) in cell culture. Antimicrob. Agents Ch. 1987, 31, 1238-1242.

4. Beauchamp, L.M.; Orr, G.F.; De Miranda, P.; Burnette, T.; Krenitsky, T.A. Amino acid ester prodrugs of acyclovir. Antivir. Chem. Chemoth. 1992, 3, 157-164. 
5. Seibert, W. Über den mechanismus der reaction von Kishner-Wolf-Staudinger, I. Mi Heilung. Chem. Ber. 1947, 80, 494-502.

6. Handschumacher, R.E.; Welch, A.D. Microbial studies of 6-azauracil, an antagonist of uracil. Cancer Res. 1956, 16, 965-969.

7. Sorm, F.; Jakubovic, A.; Slechta, L. The anticancerous action of 6-azauracil (3,5-dioxo2,3,4,5tetrahydro-1,2,4-triazine). Experientia. 1956, 12, 271-271.

8. Calabresi, P. Current status of clinical investigations with 6-azauridine, 5-iodo-2'-deoxy-uridine, and related derivatives. Cancer Res. 1963, 23, 1260-1267.

9. Creasy, W.A.; Fink, M.E.; Handschumacher, R.E.; Calabresi, P. Clinical and pharmacological studies with $2^{\prime}, 3^{\prime}, 5^{\prime}$-triacetyl-6-azauridine. Cancer Res. 1963, 23, 444-453.

10. De Clercq, E.; Descamps, J.; Verhelst, G.; Waker, R.T.; Jones, A.S.; Torrence, P.F.; Shugar, D. Comparative efficacy of antiherpes drugs against different strains of Herpes Simplex Virus. J. Infect. Dis. 1980, 1, 563-574.

11. Ruth, J.L.; Cheng, Y.C. Selective antiviral agents. J. Biol. Chem. 1982, 257, 10261-10264.

12. Robins, M.J.; Hatfield, P.W. Nucleic acid related compounds. 37. Convenient and high-yield synthesis of $N$-[2-hydroxy(ethoxy)methyl] heterocycles as 'Acyclic nucleoside' analogues. Can. J. Chemistry. 1982, 60, 547-553.

13. Senkus, M. Reaction of some cyclic acetals with acid anhydride. J. Am. Chem. Soc. 1946, 68, 734-736.

14. Keyser, G.E.; Bryant, J.D.; Barrio, J.R. Iodomethylethers from 1, 3-dioxolane and 1, 3-oxathiolane: Preparation of acyclic nucleoside analogues. Tetrahedron Lett. 1979, 35, 3263-3264.

15. Perrin, D.D.; Armarengo, W.L.F. Purification of Laboratory Chemicals, 3rd ed., Pergamon Press, New York, 1988.

16. Chang, P.K. Synthesis of some 5-alkyl-6-azauracils. J. Org. Chem. 1958, 23, 1951-1953.

17. Vorbrüggen, H.; Krollikiewicz, K.; Benua, B. Nucleoside synthesis with trimethylsilyl triflate and perchlorate as catalyst. Chem. Ber. 1981, 114, 1234-1235.

18. Lalonde, M.; Chan, T.H., Use of organosilicon reagents as protective groups in organic synthesis. Synthesis, 1985, 817-845

19. Han, C.H.; Chen, Y.L.; Tzeng, C.C. Synthetic studies on the acyclic nucleosides of 5-substituted-6azuracils. Nucleos. Nucleot. 1991, 10, 1391-1406.

20. Kelly, J.L.; Kelsey, J.E.; Hall, W.R. Pyrimidine acyclic nucleosides. 1-[(2-hydroxyethoxy) methyl] pyrimidines as candidate antivirals. J. Med. Chem. 1981, 24, 753-756. 